\title{
ANALYSIS OF LEXICAL-SEMANTIC AND STYLISTIC DEVICES OF FAIRY TALES BY OSCAR WILDE
}

Reshytko A. D.

Викладач-стажист

ORCID ID 0000-0002-7891-7092

Education and Research Institute for business technologies "UAB",

Sumy State University

57, Petropavlivska Street, Sumy, 40000, Ukraine

h.reshytko@uabs.sumdu.edu.ua

The problem of studying the language world is closely connected with the problem of conceptual picture of the world, reflecting the specificity of man and his life, his relationships and the world, the conditions of its existence. Ukrainian and English tales differ in certain national characteristics, and especially - the specifics in terms of disclosure of national character, which is shown on the conceptual level.

Tales of Oscar Wilde on the structural and semantic content are different from the folk tale. They are more vivid, emotional and written by wonderful literary and artistic language. Word of Oscar Wilde consists of three aspects of connotation: emotional, expressive and evaluative. All three components are linked: each word has a definite assessment of the writer and at the same time it is emotional, figurative and expressive.

Lexical structure of fairy tales of Oscar Wilde is quite diverse. First, it is associated with a variety of the pieces of Irish writer. Very often in a fairy tale there are different historical layers, different cultures, beliefs and customs that can not affect the language of work.

In fairy tales Wilde contains a rich arsenal of figurative-expressive means. First of all, the Irish writer is a great master of insult, which is based on metaphor. In the most common metaphor stylistic expressive means in tales of O. Wilde are: personification, comparison, epithet, the irony. There they can find examples of hyperbole, metonymy and pun even though these examples are few. Considered in this paper expressive stylistic means is a sign of personal style of Oscar Wilde and help distinguish his artistic creations of works of other authors.

Touching upon the problem of translation of Wilde fairy tales in Ukrainian language, we concluded that the most difficult problem is the problem of the ownership style. Comparing translations of some of his tales from the original text, we concluded that many of them are pronounced with Ukrainian national characteristics, which finds expression in selected translators vocabulary and idioms. While at the same time there are very good candidates who translate some of his tales, which were noted by us in this work.

Another, equally important problem is the translation of metaphor and third person singular pronouns he and she. We conclude that most translators do not take into account the fact that Oscar Wilde gave his heroes masculine or feminine, arising from the content of what he put in his work We managed to prove that the full "untranslated things" in this case does not exist, although there is no single recipe translation, which managed to save the family tale character. Each case is individual and requires not only knowledge of the specifics, but the outlook of the writer.

Key words: fairy tale, lexical-semantic and stylistic devices, epithet, metaphor, translation, language.

(с) Решитько А. Д., 2019 


\section{Introduction}

Translation is the transmission of the meaning of text in the source language using equivalent text in the target language. Translation is a complex and multifaceted type of human activity. As you know, you do not just replace one language with another language during the translation process. The translation process encounters different cultures, different personalities, different thinking structures, different literature, different epochs, different levels of development, different traditions and installations.

Each language creates a kind of "language image of the world" that "reflects the everyday, empirical, cultural or historical experience of a language group".

The product of linguistic folk consciousness as a materialization of the experience of generations and individual representatives of this people is a fairy tale, which is a wonderful work of art, a wonderful fantasy world in which horses fly over the sky, palaces grow in one night and animals speak in a human voice. Fairy tale is a kind of story, in which there are usually folklore fantasy characters, such as fairies, goblins, elves, trolls, dwarves, giants, sirens or gnomes, and usually magic or spells. However, only a small number of stories refer to fairies. These stories can be distinguished from other folk narrations, such as legends (which usually include faith in the truthfulness of the described events) and clearly moral stories, including stories about beasts.

In less technical contexts, this term is also used to describe something blessed with extraordinary happiness, such as " a fairy tale ending " (happy end) or "a fairy tale romance " (though not all fairy tales end happily). Colloquially, "fairy tale" or "fairy story" can also mean far-stretched story.

In cultures where demons and witches are seen as real, fairy tales can combine into legends, where the narrative is perceived by both the narrator and the audience as rooted in the historical truth. However, unlike legends and epics, they usually do not contain more than superficial references to religions and real places, people and events; they are held once upon a time than not in real life.

Fairy tales can be in oral and literary form. The history of fairy tales is particularly difficult to trace because only literary forms survive. Nevertheless, evidence of literary works indicates at least that fairy tales have existed for thousands of years, although they may not be considered a genre; the name "fairy tale" was first attributed by Madame d'Aulnoy at the end of 17th century. Many of today's fairy tales have evolved from the centuries-old stories that have appeared, with different variations, in many cultures around the world. Fairy tales are still written today.

Older stories were intended for the audience of both adults and children, but were associated with children; The Grimm brothers titled their collection Children's and Household Tales, and the link with children has became stronger with time.

In this work we studied the national specifics of English fairy tales and the analysis of lexical-semantic and stylistic devices of fairy tales by Oscar Wilde in terms of theory and practice of translation, so the object of this research is his fairy tales.

Creativity Oscar Wilde was the topic of numerous researchers: A. Kovalev, J. Lanhlad, Sokolyansky and many others. However, firstly, most of these works Wilde devoted to little space, and secondly, these researchers, with few exceptions, consider mainly literary and artistic features of the English writer. The language of his artistic creations tend to remain "behind the scenes." But the most valuable source for the study of literary work is his artistic language, lexical and stylistic features which has fully reveal the ideological and moral feature of any product [3:77].

As for specific translation products of Wilde into other languages, including the Ukrainian language, the research in this area I have not been identified.

Thus, the theme chosen for research, not only is relevant in itself. It is present also some element of novelty, because, despite the existence of numerous works in the field of lexicology and stylistics related art of drawing tools in a certain product, none of the researchers (both Ukrainian and foreign) are not addressed fully in linguistic and stylistic features of art Wilde, and certainly not considered from this point of view of his tales. 
Before start the work I had an aim to discover such tasks: to expose maintenance of concepts "the world picture" and "language picture of the world"; to give determination of fairy-tale, considering origin etymology of this term; to consider the national and cultural specific of fairy-tale genre; to define the genre and lingual-stylistic features of fairy tale, including to the literary fairytale; to educe the specific of translation of fairy-tales from English into Ukrainian; to consider genre and artistic originality of Oscar Wilde's fairy-tales; to give the lexicosemantic and lingually-stylistic analysis of Oscar fairytales; to define the problem of artistic translation of Oscar Wilde's fairy-tales.

\section{Results of research}

English is the language of words, that concretes objects and abstract concept designates human emotions. The word is the main language unit, which determines its special character among other semiotic systems. The word in the artistic picture of Oscar Wilde's world is the connecting link that unites the conceptual signs. An important feature of O. Wilde is the lexical repetition. Repeating several times the same word, the writer emphasizes the reader's attention on the topic that he reveals in the tale [2: 78].

A lot of events in O. Wilde's fairy tales take place in the garden; we can say that the concept of "garden" plays an important role in the perception by the writer.

The garden appears in all of Wilde's tales. The "Devoted Friend" has Han's "lovely garden":

Sweet-william grew there, and Gilly-flowers, and Shepherds'-purses, and Fair-maids of France. There were damask Roses, and yellow Roses, lilac Crocuses, and gold, purple Violets and white. Columbine and Ladysmock, Marjoram and Wild Basil, the Cowslip and the Flower-deluce, the Daffodil and the Clove-Pink bloomed or blossomed in their proper order as the months went by, one flower taking another flower's place, so that there were always beautiful things to look at, and pleasant odours to smell (9: 54).

The same garden, strange but beautifull, we can see on the pages of the fairy tale "The Selfish Giant":

It was a large lovely garden, with soft green grass. Here and there over the grass stood beautiful flowers like stars, and there were twelve peach-trees that in the spring-time broke out into delicate blossoms of pink and pearl, and in the autumn bore rich fruit. The birds sat on the trees and sang so sweetly that the children used to stop their games in order to listen to them (9: 43).

Thus, the theme of life and death, in the fairy tale "The Nightingale and the Rose", is manifested by contrasting the lexical units of sweet (life is the beautiful gift by Creator) and the shadow (the approach of death that prepares the soul to the "world of shadows"), the meaning which is revealed through the lexical repetition.

Sweet is the scent of the hawthorn, and sweet are the bluebells that hide in the valley... (9: 34)

Солодкі пахощі глоду, милі сині дзвіночки в долині...(7: 21)

O. Wilde's word has the highest degree of connotative meaning. As we know, any lexical or phraseological unit consists of three: sygnificative, denotative and connotative. 
Some linguists believe that the selection of these components is possible only theoretically. However, it should be noted that the connotative component of the lexical value is related with the figurative reflection of the object, so it plays a huge role in the word creation in the O. Wilde's tales [2: 55].

Oscar Wilde's negative characteristic is always graphic. Moreover, as a rule, he doesn't convict fairy-tale's characters himself, he allows characters to do this important task, investing in their own language, authorship, thoughts and feelings.

$$
\text { "What is a sensitive person?" said } \quad-\text { як иче - чутлива особа? - }
$$

the Cracker to the Roman Candle. - "A запитала Петарда в Римської Свічі.

person who, because he has corns himself, $\quad$ - Це та людина, яка неодмінно always treads on other буде віддушувати іншим мозолі, якщзо people's toes," answered the Roman він сам від них страждає,- шепнула Candle in a low whisper ("The Remarkable Rocket") (9: 77). («Чудова ракета») (7: 55) that:

Oscar Wilde really enjoyed the jewelry. Describing The Happy Prince, the writer says

"he was gilded all over with thin leaves of fine gold, for eyes he had two bright sapphires, and a large red ruby glowed on his sword-hilt" ("The Happy Prince") (9: 13).

The young king in the fairy tale "The Fisherman and his Soul" often used to send merchants to India to buy:

"gauze and stained ivory, «серпанок $i$ розфарбовану moonstones and bracelets of jade, слоновую кістку, місячні камені $\check{u}$ sandalwood and blue enamel and shawls of браслети з нефриту, сандал, блакитну fine wool" " ("The Young King”) (9: 98). фініфть і тонкі вовняні шалі» («Молодий Король») (7: 70).

Amount of clothing and various fashion accessories also really impress. Let's read the description of O. Wilde's heroine from the fairy tale "The Birthday of The Infanta": embroidered with silver, and the stiff corset
"Her robe was of grey satin, the skirt and the wide puffed sleeves heavily studded with rows of fine pearls. Two tiny slippers with big pink rosettes peeped out beneath her dress as she walked. Pink and pearl was her great gauze fan, and in her hair, which like an aureole of faded gold stood out stiffly round her pale little face, she had a beautiful white rose" (9: 118).

На ній було сіре атласне вбрання, спідниия ци широкі рукави буфами розшиті були сріблом, а твердий корсаж засіяний рядами прекрасних перлин. При кожному кройі 3-під плаття визирали туфельки 3 рожевими помпонами. Ї̈ віяло 3 рожевого серпанку покривали перлини, а y волоссях, які блідо-золотим ореолом обрамляли ї, була прекрасна біла троянда. (7: 86).

Fairy- tale "The Remarkable Rocket" shows us all characters as various types of pyrotechnic and technical devices. Their names in this work became the Proper, although they also refer to the terminological vocabulary: Catherine-Wheel, Squib, Cracker, the Roman Candle, Bengal Light, Rocket.

In general, the lexical structure of O.Wilde's tales consists mostly of literary-book vocabulary, which, as we have already said, has a connotative meaning; it has expressive, emotional and evaluative components. Such vocabulary gives the product extraordinary elegance, selectivity and gracefulness:

"He passed by the cathedral tower, where the white marble angels were sculptured. He passed by the palace and heard the sound of dancing. A beautiful girl came out on the balcony with her lover.
Вона пролетіла над дзвіничею собору, де коштують біломармурові статуї ангелів. Вона пролетіла над королівським палацом $i$ чула звуки 
"How wonderful the stars are," he said to her, "and how wonderful is the power of love!" ("The Happy Prince”) (9: 17). музики. На балкон вийшла гарна дівчина, $i$ з нею ї̈ коханий.

- Яке чудо иі зірки, - сказав їй коханий, - $і$ як чудесна влада любові! («Щасливий принци) (7: 10).

It is very difficult to find conversational lexical units in the O. Wilde's tales. Even such characters as Hans and Miroshnik from the fairy tale "The Devoted Friend" - speak with each other in good English, with no plain phrases and expressions, as usually happens in folk tales:

"Hans, I am surprised at you," said the Miller; "friendship never forgets. That is the wonderful thing about it, but I am afraid you don't understand the poetry of life. How lovely your primroses are looking, by-the-bye!" "'They are certainly very lovely," said Hans, "and it is a most lucky thing for me that I have so many. I am going to bring them into the market and sell them to the Burgomaster's daughter, and buy back my wheelbarrow with the money." (9: 58).

We must pay attention on one more peculiarity: when $\mathrm{O}$. Wilde tells in his fairy tale about the events of "long past days", drawing strange pictures of the people's life who lived hundreds or even million years ago, in this case he transmits the language by his heroes, using outdated grammatical forms. So, Fisherman from the fairy tale "The Fisherman and his Soul" says:

"Thou art the best of the witches and I will surely dance with thee to-night on the top of the mountain. I would indeed that thou hadst asked of me either gold or silver. But such as thy price is thou shalt have it, for it is but a little thing. " (9: 154).

English, as well as any developed language with a long cultural tradition, provides the richest expressiveness, including lexical-stylistic. One of the richest means of stylistic expressiveness of the language is the so-called tools of verbal imagery.

Expressive-figurative means of speech are called "all kinds of figurative use of words, phrases and phonemes, combining all types of portable names with the general term" trails.

The most characteristic stylistic unit is a metaphor. A metaphor is a figure of speech that describes an object or action in a way that isn't literally true, but helps explain an idea or make a comparison. A metaphor is a figure of speech that, for rhetorical effect, directly refers to one thing by mentioning another. It may provide clarity or identify hidden similarities between two ideas. Antithesis, hyperbole, metonymy and simile are all types of metaphor.

Metaphors can make your words come to life (or in the case of the exam, to death). Often, you can use a metaphor to make your subject more relatable to the reader or to make a complex thought easier to understand. They can also be a tremendous help when you want to enhance your writing with imagery. As a common figure of speech, metaphors turn up everywhere from novels and films to presidential speeches and even popular songs. When they're especially good, they're hard to miss.

The Philosophy of Rhetoric (1937) by rhetorician I. A. Richards describes a metaphor as having two parts: the tenor and the vehicle. The tenor is the subject to which attributes are ascribed. The vehicle is the object whose attributes are borrowed. In the previous example, "the world" is compared to a stage, describing it with the attributes of "the stage"; "the world" 
is the tenor, and "a stage" is the vehicle; "men and women" is the secondary tenor, and "players" is the secondary vehicle [4:150].

Other writers employ the general terms ground and figure to denote the tenor and the vehicle. Cognitive linguistics uses the terms target and source, respectively

Here is an example of the metaphor from O. Wilde's fairy tale The Selfish Giant:

"Who hath dared to wound thee?" | "Хто посмітив нанести тобі иі cried the Giant, "tell me, that I make take рани? - закричав Велетень. - Скажи my big sword and slay him."

"Nay," answered the child: "but винного" - "Hixmo! - відnовіло дumя- -

these are the wounds of Love." (9: 48). $\quad$ Адже ці рани породила Любов" (7: 46).

This example shows us direct meaning of the verb "wound" - "hurt or injury to the living tissue of the body, caused by cutting, shooting, tearing, etc., esp. as the result of attack "turned into the metaphorical noun "the wounds of Love". The writer wants to say that love will also hurt - not physically, but mentally.

An important means of disclosing an artistic image of tales by $\mathrm{O}$. Wild is the comparison. Comparison is a feature in the morphology or syntax of some languages, whereby adjectives and adverbs are inflected or modified to indicate the relative degree of the property defined by the adjective or adverb. The comparative expresses a comparison between two (or more) entities or groups of entities in quality, quantity, or degree; the superlative is the form of an adverb or adjective that is the greatest degree of a given descriptor.

The grammatical category associated with comparison of adjectives and adverbs is degree of comparison. The usual degrees of comparison are the positive, which simply denotes a property (as with the English words big and fully); the comparative, which indicates greater degree (as bigger and more fully); and the superlative, which indicates greatestdegree (as biggest and most fully). Some languages have forms indicating a very large degree of a particular quality (called elative in Semitic linguistics). Other languages (e.g. English) can express lesser degree, e.g. beautiful, less beautiful, least beautiful.

O. Wilde's comparisons are figurative, based on a metaphor. Therefore, such comparisons were called metaphorical.

O.V. Kovalev notes that "Wilde comes to a substantive interpretation of the image, emphasis on material substance, embodiment of which is carried out through the objective metaphor, more precisely," objective "metaphorical comparison" [2: 91].

Let's analyze the example of metaphorical comparison taken from the fairy tale "The nightingale and the rose":

"But the Tree shook its head. $\quad$ Але Рожевий Кущ покачав

"My roses are red," it answered; головою. - Мої троянди червоні, -

"as red as the feet of the dove, and redder відповів він, - вони червоні, як лапки than the great fans of coral that wave and голублячи, вони червоніше коралів, що wave in the ocean-cavern" (9:33). $\quad$ колишуться, як віяло, у печерах на дні океану (7: 21).

We can see a comparison based on the formal index as ... as. But the following is followed by another comparison, created by a simple comparative form of the adjective red. The difference between the first and second comparison is that in the first case the author told about the "equality" of the compared objects (red rose = red claws digging), and in the second case the colors of the rose are stronger than the color of the corals lying on the ocean's bottom.

Another expressive means characterizing the author's style is the epithet, which can be defined as "emotionally-evaluative or expressive-figurative (metaphorical) definition of a certain denotate.

Epithets are sometimes attached to a person's name or appear in place of his or her name, as what might be described as a glorified nickname or sobriquet. An epithet is linked to its noun by long-established usage. Not every adjective is an epithet. An epithet is especially recognizable when its function is largely decorative, such as if "cloud-gathering Zeus" is 
employed other than in reference to conjuring up a storm. "The epithets are decorative insofar as they are neither essential to the immediate context nor modeled especially for it. Among other things, they are extremely helpful to fill out a half-verse", Walter Burkert has noted.

Some epithets are known by the Latin term epitheton necessarium because they are required to distinguish the bearers, e.g. as an alternative to numbers after a prince's namesuch as Richard the Lionheart (Richard I of England), or Charles the Fat alongside Charles the Bald. The same epithet can be used repeatedly joined to different names, e.g. Alexander the Great as well as Constantine the Great. Other epithets can easily be omitted without serious risk of confusion, and are therefore known (again in Latin) as epitheton ornans [6:416].

Let's consider the peculiarities of the functioning and the stylistic role of the varieties of the epithet on the example of Oscar Wilde's fairy tales, in which there are two types of epithets: epithets without violating the semantic harmony and epithets with a violation of semantic harmony.

I. Epithets without violating the semantic harmony

a) conversational (standing) epithet

Conversational (standing) epithet is a stable phrase such as: green wood, lady gay, fair lady, fair England, salt seas, true love, which saved figurativeness despite often using in poetry and folklore. In prose such epithets become standing. For example:

$$
\text { "It is winter," answered the - тепер зима, - відповіла }
$$

Swallow, "and the chill snow will soon be Ластівка, - $i$ незабаром тут niде here". ("The Нарру Prince”) (9: 20). $\quad$ холодний сніг» («Щасливий Принц») (7: $13)$.

The word "chill" means "unpleasantly cold". In this context, the combination of "chill snow" has emotional negative-evaluative meaning.

Epithets, which denote colors, are very picturesque and emotional. They perform the descriptive function. For example:

"In Egypt the sun is warm on the green palm trees, and crocodiles lie in the mud and look lazily about them" ("The Happy Prince") (9: 20).
«А в Сгипті сонце зігріває зелені листи пальм, і крокодили витягнулися в тину й ліниво дивляться по сторонах» («Щасливий Приниџ) (7: 13).

In this context, the adjectives "warm" and "green" contribute the reproduction of the situation.

However, in most cases, grammatical transformations are inevitable. For example, the sentence "In Egypt the sun is warm on the green palm trees, and the crocodiles lie in the mud and look lazily about them" (The Happy Prince) (9:20) was translated as: «А в Сгипті соние зігріває зелені листи пальм, і крокодили витягнулися в тину й ліниво дивляться по сторонах» (7: 13). The adjective "warm" was tranformated into the verb and became a predicate.

b) expositive epithet

The expositive epithet shows an important feature, which characterised the whole class of objects. For example:

"How selfish I have been!.. Now I $\quad$ - Який же я був егоїст - сказав know why the spring would not come here." він. - Тепер я знаю, чому Весна не (9: 46). хотіла прийти в мій сад. (7: 30).

Selfish - is "deficient for consideration for others". This epithet reveals lineament.

These epithets often change their grammatical status after translating and become another part of speech, mostly nouns.

II. Epithets with a violation of semantic harmony

Such epithets, as a rule, follow the prescribed word.

"The chestnut had its spires of white stars, and the hawthorn its pallid moons of beauty" ("The Birthday of the Infanta") (9: 137). 
The epithet plays the leading role in all works by Oscar Wilde. It expresses an author's assessment.

We can say that these expressive stylistic tools are individual Oscar Wilde's style. Metaphor, comparison and epithet are "business card" of the writer and help to distinguish his works from other authors.

One of the mostly used stylistic techniques in literature is irony. Some linguists view irony in a narrow and broad sense. So the irony (in more narrow sense) is the use of the word, which usually expresses a positive assessment for the negative evaluation. For example:

"Real friends should have «Усправжніх друзів все повинне everything in common," the Miller used to бути спільним», - говорив Мірошник, а say, and little Hans nodded and smiled, and Маленький Ганс посміхався й кивав felt very proud of having a friend with such головою: він дуже пишався, що в нього $\epsilon$ noble ideas" ("The Devoted friend") (9: друг з такими шляхетними поглядами. $55)$. (7: 36).

We can find other expressive tools in Wilde's tales. For example hyperbole. This expressive tool helps the author to enhance the impression, emphasize the positive or negative quality of the described person or subject.

In O. Wilde's tales, hyperbole often interacts with other stylistic tools such as metaphor, personalization and comparison.

For example, at the beginning of the fairytale The Selfish Giant, O. Wilde, tells us about Giants and try to emphasize that the flowers in his garden were as huge as:

"Here and there over the grass $\quad$ «Iз трави отут і там, немов stood beautiful flowers like stars..." (9: зірки, визирали віночки прекрасних 43)... квітів»(7: 27).

In the fairy tale "The Happy Prince" the swallow tells the Prince about Egypt where the bird wants to fly:

"At noon the yellow lions come down to the water's edge to drink. They have eyes like green beryls, and their roar is louder than the roar of the cataract" (9: 18).

These examples show us the connection between hyperbole and comparison.

It is impossible to forget about metonymy. Metonymy is a figure of speech in which a thing or concept is referred to by the name of something closely associated with that thing or concept.

Although literally a pen has no power over a sword, we understand this phrase means that the written word and the sharing of ideas are more powerful than fighting or physical force. This phrase uses metonymy, which is a figure of speech that replaces words with related or associated words. A metonym is typically a part of a larger whole, for example, when we say "wheels," we are figuratively referring to a "car" and not literally only the wheels. So, "wheels" are the associated part that represents the whole car. In the example above, we replaced "written words" with "the pen." The word metonymy is derived from the Greek phrase metonymía meaning "a change of name." [1:296] Example of metonymy in the fairy tale "The Happy Prince":

"And now that I am dead they have set me up here so high that I can see all the ugliness and all the misery of my city" (9: 16).

Metonymy in O. Wilde's tales is found less frequently then other expressive tools and, as a rule, does not cause problems in translation. However, I would like to pay your attention to the translation of the word city, which was translated not as a "місто" but as a 
"столиця":«И от тепер, коли я вже неживий, мене поставили тут, нагорі, так високо, що мені видні всі скорботи й вся вбогість моєї столиці» (7: 8).

The translator understrand that the events take place in the capital, as the word "city" describedes the larger cities (small cities are translated into the word "town"). But the big city is not only the capital of the country (so, for example, Washington is a USA city, but New York is also a city, though it is not a capital.).

The pun is a stylistic tool, a game of words, based on the comic flip of consonant words or phrases with incompatible values. The punis based on polysemias, homonyms, homographs and humorous etymologizations of words. The connection of incompatible concepts, built on the consonants of words, will lead to a semantic absurdity and create a comic effect.

We can not say that O. Wilde is a master of puns, but such techniques we found in his tale "The Remarkable Rocket".

I.

"Hallo!" he cried, "what a bad rocket!" and he threw him over the wall into the ditch.

"BAD Rocket? BAD Rocket?" he said, as he whirled through the air; "impossible! GRAND Rocket, that is what the man said. BAD and GRAND sound very much the same, indeed they often are the same"; and he fell into the mud (9: 81).

II.

"Hallo!" cried one of the boys, "look at this old stick! I wonder how it came here"; and he picked the rocket out of the ditch.

"OLD Stick!" said the Rocket, "impossible! GOLD Stick, that is what he said. Gold Stick is very complimentary. In fact, he mistakes me for one of the Court dignitaries!" (9: 87).

«- Гляньте! - крикнув ией слуга. - Отут якась негідна Ракета! - I він жбурнув ї̈ за огорожу, прямо в канаву.

- Негідна Ракета? Негідна

Ракета? - викликнула вона, перероблячи через огорожу. - Цього не може бути! Чудова Ракета - от щзо повинна була сказати ия людина. Негідна $i$ Чудова звучать майже однаково, так, по суті, дуже часто й означають те саме. - I із иими словами вона ильопнулася прямо в бруд» (7: 60).

«Дивись суди! - крикнув один із хлопчиків. - Геть якийсь брудний иіпок! Цікаво, як вона сюди потрапила. - І він витяг Ракету з канави.

- Брудний Ціпок! - сказала Ракета. - Нечувано! Грізний Ціпок хотів він, очевидно, сказати. Грізний Ціпок - це звучить дуже лестно. Мабуть, він прийняв мене за один із придворних Сановників» (7: 65).

There is no doubt that these two puns create an ironic effect.

\section{Conclusions}

The problem of studying the language world is closely connected with the problem of conceptual picture of the world, reflecting the specificity of man and his life, his relationships and the world, the conditions of its existence.

Ukrainian and English tales differ in certain national characteristics, and especially - the specifics in terms of disclosure of national character, which is shown on the conceptual level.

Tales of Oscar Wilde on the structural and semantic content are different from the folk tale. They are more vivid, emotional and written by wonderful literary and artistic language.

Word of Oscar Wilde consists of three aspects of connotation: emotional, expressive and evaluative. All three components are linked: each word has a definite assessment of the writer and at the same time it is emotional, figurative and expressive. 
Lexical structure of fairy tales of Oscar Wilde is quite diverse. First, it is associated with a variety of the pieces of Irish writer. Very often in a fairy tale there are different historical layers, different cultures, beliefs and customs that can not affect the language of work.

In fairy tales Wilde contains a rich arsenal of figurative-expressive means. First of all, the Irish writer is a great master of insult, which is based on metaphor. In the most common metaphor stylistic expressive means in tales of O.Wilde are: personification, comparison, epithet, the irony. There they can find examples of hyperbole, metonymy and pun even though these examples are few.Considered in this paper expressive stylistic means is a sign of personal style of Oscar Wilde and help distinguish his artistic creations of works of other authors.

Touching upon the problem of translation of Wilde fairy tales in Ukrainian language, we concluded that the most difficult problem is the problem of the ownership style. Comparing translations of some of his tales from the original text, we concluded that many of them are pronounced with Ukrainian national characteristics, which finds expression in selected translators vocabulary and idioms. While at the same time there are very good candidates who translate some of his tales, which were noted by us in this work.

Another, equally important problem is the translation of metaphor and third person singular pronouns he and she. We conclude that most translators do not take into account the fact that Oscar Wilde gave his heroes masculine or feminine, arising from the content of what he put in his work We managed to prove that the full "untranslated things" in this case does not exist, although there is no single recipe translation, which managed to save the family tale character. Each case is individual and requires not only knowledge of the specifics, but the outlook of the writer.

національна специфіка англійської казки й проведений аналіз лексико-семантичних $i$ стилістичних засобів казок Оскара Уайльда в аспекті теорї̈ й практики перекладу

\section{АНАЛІЗ ЛЕКСИКО-СЕМАНТИЧНИХ ТА СТИЛІСТИЧНИХ ЗАСОБІВ КАЗОК ОСКАРА УАЙЛЬДА}

Решитько А. Д.

Викладач-стажист

ORCID ID 0000-0002-7891-7092

Інститут бізнес-технологій "УАБС"

Сумського державного університету

вул. Петропавлівська, 57, м.Суми, 40000, Україна

h.reshytko@uabs.sumdu.edu.ua

У роботі була вивчена наиіональна специффіка англійської казки й проведений аналіз лексико-семантичних і стилістичних засобів казок Оскара Уайльда в аспекті теорії ци практики перекладу. Продуктом мовної народної свідомості як матеріалізаиї досвіду поколінь й окремих представників даного народу є казка, яка є прекрасним твором мистеитва, дивний світ фантазії, де коні літають по небу, палачи виростають за одну ніч, а звірі говорять людським голосом.

Казка вважається загальнодоступним жанром, але саме він виявляється одним з найбільш загадкових в історії народної творчості. Казки зіграли велику роль й у творчому становленні ірландського письменника останньої чверті ХІХ століття Оскара Уайльда. Казки Оскара Уайльда по своій структурі й значеннсвому змісті відрізняються від фольклорної казки. Вони більш образні, емоційні й написані прекрасною літературно-художньою мовою.

Слово в художньо-образній картині світу О. Уайльда є тією сполучною ланкою, щзо поєднує понятійні знаки, тобто концепти. Слово в Оскара Уайльда володіє насамперед образністю й досить високої конотаиією, що складається із трьох аспектів значення: емочійного, експресивного й оцінного. Всі йі три 
компоненти зв'язані між собою: кожне слово письменника має певну оцінку й у той же час воно емоиійно, образно, і експресивно.

Дана робота присвячена мовностилістичним особливостям казок О. Уайльда. У казках О. Уайльда втримується багатий арсенал зображувальновиразних засобів. У ході даного дослідження ми використали метод лінгвістичного аналізу й порівняльно-порівняльний аналіз. Розглянуті в даній роботі виразні стилістичні засоби є ознакою індивідуального стилю Оскара Уайльда й допомагають відрізнити його художні утвори від творів інших авторів.

Ключові слова: казка, лексико-семантичні та стилістичні особливості, епітет, метафора, переклад, мова.

\section{СПИСОК ВИКОРИСТАНИХ ДЖЕРЕЛ}

1. Арнольд И.В. Стилистика современного английского языка. - Л.: Просвещение, 1981. - $296 \mathrm{c}$.

2. Ковалева О.В. О. Уайльд и стиль модерн. - М.: Едиториал УРСС. - 2002. - 168 с.

3. Ланглад Ж. Оскар Уайльд, или правда масок. - М.: Молодая гвардия : Палимпсест, 1999. - $325 \mathrm{c}$.

4. Скляревская Г. Н. Метафора в системе языка. - СПб.: Наука, 1993. - 150 с.

5. Соколянский М. Г. Оскар Уайльд: Очерк творчества. - Киев - Одесса: Лыбидь, 2002. - 199 c.

6. Федоров А.В. Основи загальної теорії перекладу. - М: Видавничий Будинок «Філологія Три» // Спб: Філологічні факультети Спбгу, 2002. -416 с.

7. Уайльд О. Кентервильское привидение. Сказки. - М.: АСТ-Пресс, 1993. - 384 с.

8. Folk Tales of the British Isles. - M.: Raduga Publishers, 1987. - 368 p.

9. Teaching Translation: Objectives and Methods Кобякова І.К., Швачко С.О. http://essuir.sumdu.edu.ua/handle/123456789/45366

10. Wilde O. Fairy Tales and Stories. - Czechoslovakia: Octopus Books, 1980.

\section{REFERENCES}

1. Arnold I.V. The style of modern English. - L .: Enlightenment, 1981. - 296 p.

2. Kovaleva O.V. O. Wilde and modern style. - M .: Editorial URSS. - 2002. - 168 p.

3. Langlad J. Oscar Wilde, or the truth of the masks. - M .: Young Guard: Palimpsest, 1999. -325 p.

4. Sklyarevskaya G.N. Metaphor in the language system. - SPb .: Science, 1993. - 150 p.

5. Sokolyansky M. G. Oscar Wilde: Essay on Creativity. - Kiev - Odessa: Lybid, 2002. $199 \mathrm{p}$.

6. Fedorov A.V. Establish the theory of translation. - M: Vidavnichiy Budinok "Philology of Three" // Spb: Philology of the Faculty of St. Petersburg, 2002. -416 p.

7. Wilde O. Canterville Ghost. Fairy tales. - M .: AST - Press, 1993. - 384 p.

8. Folk Tales of the British Isles. - M.: Raduga Publishers, 1987. -368 p.

9. Teaching Translation: Objectives and Methods Кобякова I.К., Швачко С.О. http://essuir.sumdu.edu.ua/handle/123456789/45366

10. Wilde O. Fairy Tales and Stories. - Czechoslovakia: Octopus Books, 1980.

Received: 28 March, 2019 